\title{
Evaluation of Some Egyptian Cotton Cultivars for Yield, Seed Quality and Viability Characters. \\ Shakr, S. A. ${ }^{1}$ Eman N. M. Mohamed ${ }^{2}$ and Alaa M. E. A. Shahein ${ }^{2}$ \\ ${ }^{1}$ Cotton Res. Institute, Agric. Res. Center, Giza, Egypt. \\ ${ }^{2}$ Seed Technology Res. Sec. Field Crop Res. Inst. Agric. Res. Center, Egypt.

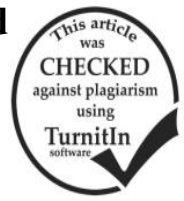

\section{ABSTRACT}

The present investigation aimed to evaluate some Egyptian cotton cultivars i.e.: Giza 86, Giza 94, Giza 87, Giza 88, Giza 92, Giza 93 and Giza 96 under three different locations in Lower Egypt (Delta) during the two successive growing seasons of 2015 and 2016 for yield, seed quality and viability characters. Randomized complete block design with three replications was used at each location. Significant differences for cultivars and locations for all studied characters, except free fatty acid and acid value. The effects of the growing years, interactions between (genotype $\mathrm{x}$ seasons), (location $\mathrm{x}$ season) and the second order interaction were significant on most studied characters, Also the effect of the interaction between (genotype $\mathrm{x}$ locations) was significant for all studied characters, except for seed cotton yield and lint percentage. Giza 94 and Giza 92 surpassed in seed cotton yield, boll weight, lint percentage and seed index. The cultivar Giza 92 gave the highest oil \% and germination, while, Giza 96 produced the highest radical length, shoot length and seedling dry weight, while. Giza 88 surpassed all studied cultivars in protein \%.Positive significant correlations were found between seed cotton yield and both boll weight and seed index, lint percentage and each (boll weight, seed volume and seed coat), boll weight and seed coat \%, seed index and both (seed volume and seedling dry weight), free fatty acid and acid value, protein $\%$ and seed coat $\%$, seed volume and seedling dry weight, germination $\%$ and both (shoot length and seedling dry weight), shoot length and seedling dry weight.

Keyword: Egyptian cotton cultivars, locations, cotton yield, seed quality and viability characters.

\section{INTRODUCTION}

Improving cotton quality through introducing cultivars is the most important objective of the Cotton Research Inistitue. Cotton yield and seed quality are important characters, the performance of cotton cultivars under different environments was studied by several works, i.e. Badr and Soad (2004 A) studied some genotypes extra long staple i.e. G 45,G 70,G 87,G $88, \mathrm{G} 84 *(\mathrm{G} 74 \times \mathrm{x}$ 68) during two seasons for seed cotton yield, boll weight, lint percentage, seed index, oil $\%$, free fatty acid $\%$, Acid value, crude protein $\%$, moisture $\%$, seed volume, relative density, seed coat, germination \%, seedling vigor (radical length, shoot length and seedling dry weight). They found that year and year $\mathrm{x}$ location effect were significant for all traits except oil $\%$, seed volume, shoot length and seedling dry weight also, insignificant for seed coat to year effect. The location was insignificant radical length. Genotype and genotype $\mathrm{x}$ year were insignificant for free fatty acidy and acid value also, genotype insignificant for significant for all traits. The genotype $\mathrm{x}$ year $\mathrm{x}$ location percentage and seedling dry weight.

Badr and Soad (2004b) studied some genotypes long staple i.e. G 85, G 86, G 89, (G 89* G 86) and ( $\mathrm{G}$ $89 *$ piwa S6 they reported that year and crud protein year $\mathrm{x}$ location were significant for all traits except for boll weight, seed index, oil $\%$, free fatty acid, acid value, moisture $\%$ and seed coat also, year was insignificant for crude protein, seed volume and relative density. Location and genotype were insignificant for free fatty acid, acid value and seed coat also, location insignificant for relative density, genotype was insignificant for seed cotton yield. Genotype $\mathrm{x}$ year interaction was insignificant for seed cotton yield, boll weight, oil $\%$, seed coat and germination. Genotype x location was significant for all traits except seed coat.

Amal et al. (2009) reported that the effect of the difference among cotton varieties were significant for oil $\%$, protein $\%$ and gossypol content.
Amal et al. (2009) studied 8 genotypes i.e. G 45, G 70, G 85, G 86, G 88, G 89, G 80 and G 90 over 7 years found that the effect of genotype, year and the interaction between them were significant for seed oil content and protein content $\%$.

Shaker (2014) evaluated five extra long staple cotton genotypes (G. 70, G 88, G 92, \{G 84 (G 70 X G $51 \mathrm{~b} X \mathrm{G} \mathrm{62})\}, \mathrm{G} 96$ and $\mathrm{G} 77 \times \mathrm{S}_{6}$ (G 93) and detected that the mean square due to genotypes, location and year $\mathrm{x}$ location were significant for seed cotton yield, boll weight, lint percentage and seed index. While those due to year and genotype $\mathrm{x}$ year $\mathrm{x}$ location was significant for the previous characters, except for seed index. Genotype $\mathrm{x}$ year was significant for seed cotton yield and lint percentage. Genotype $\mathrm{x}$ location was significant for seed cotton yield and boll weight.

Abd El-Aty et al (2015) studied some genotypes performance i.e.( 10229 x G 86), G 94, G 45, G 70, G 85, G 86, G 87, G 88, G 92 and exchange hydride among them for half diallel found that genotype effect was significant for oil content $\%$, protein content, acid value as F1 generation (traits) as well as germination \%, seedling length, seedling vigor index, seedling fresh weight and dry weight in F2 generation for control and accelerated aging treatment. The results exhibited that seed index, seed density, were positively correlated with germination \% under control and accelerated aging conditions, seedling length and seedling vigor index under accelerated aging as well as seedling dry weight under control.

The aim of the present investigation was to evaluate some Egyptian cotton cultivars for yield, seed quality and viability characters.

\section{MATERIALS AND METHODS}

The materials consisted of seven cultivars i.e. Giza 86, Giza 94, Giza 87, Giza 88, Giza 92, Giza 93 and Giza 96 of Egyptian cotton were grow in Behira, Dakhlia and Gharbia locations for two years 2015 and 2016. 
A randomized completed block design with three replications was used at each location. Each plot $60 \mathrm{~m}^{2}$. The distance between hills was $25 \mathrm{~cm}$ and each hill was thinned to two plants. Sowing date was at during the second week of April. Cultural practices were carried out as recommended in cotton fields.

Data were collected for the following traits:

- Seed cotton yield (k/fed) obtained as weight of seed cotton yield $(\mathrm{kg})$ per plot and converted to kantar per feddan (kantar $=157.5 \mathrm{~kg})$.

- A random sample of 50 bolls was harvested at random from each plot and was used to obtain plot mean values for:

a- Boll weight in gram (BW (g)): The average weight of 50 bolls in gram.

b- Lint percentage (L \%): The weight of lint obtained a seed cotton sample.

$\mathrm{L} \%=\mathrm{L} \%=\frac{1 \text { weightofl int int hesample }(\mathrm{g})}{\text { weightofseed cot ton int hesample }}$

Physical properties of seed cotton

- Seed index and seed volume: One hundred seeds were counted and weighed. Then their volume was measured by absolute displacement method (Kramer and Twigg 1962).

-Relative density of seeds was calculated accorded to Kramer and Twigg (1962) as follows:

Relative density $=\frac{100-\text { seed weight }(\mathrm{g})}{100-\text { seed volume }\left(\mathrm{mm}^{3}\right)}=\mathrm{gm} / \mathrm{mm} 3$

-Seed coat: One hundred-gram of seeds of both samples was decorticated. The decorticated seeds and seed coats were weighed separately (Youssef, 1978 and Shehata et al., 1985a). Percentage of seed coat was calculated as follows:

Seed $\operatorname{coat} \%=$

$$
\frac{\text { wt. of seed coot }(g)}{\text { wh. of seed coat }+ \text { wt. of decoric at seeds }} \times 100
$$

-Standard germination: Test was carried out under optimum conditions according to International Rules Testing (ISTA, 1999).

-Seed vigor (seedling growth and evaluation test): Radical, shoot length and seedling dry weigh were measured according to procedures reported in the seed vigor testing handbook (ISTA, 1995), Seed vigor test do not predict percentage field emergence, but neither does standard germination. However, seed vigor test do relate better to field emergence under stressful soil conditions than does standard germination. Values obtained from seed vigor tests are relative values, not absolute values.

\section{Chemical composition characters:}

Seed sample were taken at random from each plot and grounded to fine powder to pass through $2 \mathrm{~mm}$ mesh for chemical analysis; i.e. moisture content, fat, crude protein, free fatty acids (F.F.A) and acid value (A.V) were determined according to procedures outline in AOAC (1990).

\section{Statistical analysis:}

Analysis of variance was done according to Snedecor and Chochran (1982) for each location. Combined analysis for all location was performed on all the studied traits as out lined by Mclntosh (1983). Differences between means were compared by using the least significant difference (L.S.D.) test as given by Steel and Torrie (1980).

\section{RESULTS AND DISCUSSION}

The results reported in this investigation included the evaluation of seven Egyptian cotton cultivars in the two seasons, i.e. 2015 and 2016 across three different locations of Lower Egypt in order to study the effects of genotypes, locations, years ant their interactions and the interaction between them.

Table1. Mean performance of cotton cultivars for seed cotton yield and viability and quality characters in combined analysis for three locations and two years

\begin{tabular}{lcccccccc}
\hline Characters & L.S.D & G 86 & G94 & G87 & G88 & G92 & G93 & G96 \\
\hline Seed cotton yield (k/f) & 1.04 & 9.49 & 11.61 & 7.62 & 8.75 & 9.49 & 8.91 & 9.51 \\
Boll weight (g) & 0.19 & 3.10 & 3.07 & 2.54 & 2.73 & 2.94 & 2.66 & 2.95 \\
Lint (\%) & 1.36 & 38.78 & 41.13 & 33.49 & 37.16 & 36.06 & 34.10 & 38.90 \\
Seed index (g) & 0.47 & 10.83 & 12.09 & 10.00 & 10.47 & 10.43 & 10.37 & 10.33 \\
Oil (\%) & 1.807 & 27.51 & 27.35 & 26.58 & 26.20 & 29.95 & 29.27 & 28.30 \\
Free fatty acid (\%) & N.S & 0.214 & 0.219 & 0.213 & 0.219 & 0.213 & 0.221 & 0.216 \\
Acid value & N.S & 0.426 & 0.440 & 0.430 & 0.442 & 0.442 & 0.420 & 0.446 \\
Crude protein (\%) & 0.306 & 24.27 & 24.37 & 26.39 & 27.81 & 24.203 & 23.89 & 24.25 \\
Moisture (\%) & 0.680 & 12.00 & 11.98 & 11.90 & 12.80 & 13.00 & 12.90 & 12.80 \\
Seed volume (mm3) & 0.976 & 11.90 & 12.60 & 12.50 & 13.14 & 12.67 & 12.70 & 12.95 \\
Relative density & 0.009 & 0.762 & 0.778 & 0.768 & 0.768 & 0.774 & 0.765 & 0.771 \\
Seed coat (\%) & 1.218 & 35.16 & 30.35 & 38.40 & 36.90 & 37.00 & 36.90 & 38.20 \\
Germination (\%) & 0.859 & 74.61 & 80.61 & 86.89 & 87.06 & 90.94 & 87.83 & 89.28 \\
Seedling vigor & & & & & & & & \\
(Radical length (cm) & 0.629 & 16.68 & 16.43 & 15.93 & 15.13 & 14.84 & 16.31 & 17.55 \\
(Shoot length (cm) & 0.404 & 14.22 & 15.17 & 13.52 & 13.41 & 14.51 & 15.20 & 15.95 \\
Seedling dry weight (mg) & 1.21 & 52.00 & 53.88 & 50.90 & 51.90 & 54.70 & 52.28 & 56.13 \\
\hline *** and NS indicated P<0.05\%, P<0.01\% and not significant, respectively. & & & & &
\end{tabular}

\section{1-Cultivars effect:}

Seed cotton yield, some its components, seed quality and seed viability characters of cotton cultivars in combined analysis for three locations ( Beheira, Gharbia and Dakahlia) and two seasons (2015 and 2016) are presented in Table1. The obtained results 
showed that the effect of the different cotton cultivars on all studied characters were significantly different, except for free fatty acid $\%$ and acid value.

The cultivars Giza 94 from long staple category superior in yield and its components on the rest cultivars. The cultivars Giza 96, Giza92 and Giza 88 recorded the highest yield and boll weight on all cultivars from extra long staple category; also Giza 96 superior in lint percentage for this category. However, the cultivar Giza 87 was the lowest one in yield and its components. These results confirm the findings of Hassan et al. (2013), Abd El-Salam et al. (2014) and Shaker et al. (2014). They reported that the effect of genotype was significant on yield and yield components. Giza 92, Giza 96 and Giza 93 gave the highest value for oil \% than the other genotypes, while, G 87 and G 88 were the lowest in oil\%. G 88 gave the highest value for protein $\%$, moisture $\%$ and seed coat $\%$. While, G 93 gave the lowest protein $\%$, moisture $\%$ and seed coat $\%$. The cultivar G 96 gave the highest seed volume than the other genotypes while, G 88 and G 86 gave the lowest in this respect. G 92 and G 94 gave the highest seed relative density while, G 86 was the lowest in this respect. G 92 and G 96 gave the higher germination \%. G 96 gave the higher radical length, shoot length and seedling dry weight than all genotypes. G 87 and G 88 gave the lowest in these respects. This may belong to different the gene expression for genotype to germblasm another. Also, this results in agreement with those obtained by Atteia (2001), ElDesuky (2002), Badr and Soad (2004 a), Badr and Soad (2004b), Amal et al. (2010), Hassan et al. (2013) and Abd El- Aty et al. (2015).

\section{2- Effect of different growing years:}

Table 2 shows the average values of studies characters as affected by different growing year. The combined analysis showed highly significant differences in all studied characters due to years except lint $\%$, free fatty acid, acid value and seed coat. The first season (2015) gave the significant best values for seed cotton yield, boll weight, seed index, moisture \% seedling dry weight. While, the second season (2016) gave the significant best values for oil $\%$, free fatty acid $\%$, acid value, protein $\%$, seed volume, relative density, seed coat, germination $\%$, radical length and shoot length. This may belong the different among the climatic conditions from year to year. These results are in harmony with those obtained by Badr and Soad (2004 a), Badr and Soad (2004b), Hassan et al. (2013), Abd El-Salam et al. (2014) and Shaker (2014). They reported that the effect of growing season was significant on cotton yield and some yield component characters. Also, Atteia (2001), El-Desuky (2002) and Abd El-Aty et al. (2015).they reported that this effect was significant in some cotton seed characters.

Table 2. Effect of growing season and growing locations on seed cotton yield and viability and quality character.

\begin{tabular}{|c|c|c|c|c|c|c|c|}
\hline \multirow[b]{2}{*}{ Characters } & \multirow{2}{*}{ L.S.D } & \multicolumn{2}{|c|}{ Year } & \multirow{2}{*}{ L.S.D 0.01} & \multicolumn{3}{|c|}{ Location } \\
\hline & & 2015 & 2016 & & Beheira & Gharbia & Dakahlia \\
\hline Seed cotton yield k/f & 1.21 & 10.23 & 8.45 & 1.48 & 8.66 & 10.13 & 9.23 \\
\hline Boll weight (g) & 0.16 & 2.94 & 2.77 & 0.21 & 2.59 & 2.99 & 2.99 \\
\hline Lint $(\%)$ & N.S & 36.97 & 37.21 & 0.98 & 37.81 & 36.80 & 36.66 \\
\hline Seed index $(g)$ & 0.54 & 11.35 & 9.94 & 0.66 & 9.33 & 11.45 & 11.16 \\
\hline Oil (\%) & 1.551 & 27.17 & 29.15 & 1.899 & 28.82 & 29.35 & 25.32 \\
\hline Free fatty acid (\%) & N.S & 0.210 & 0.220 & N.S & 0.199 & 0.220 & 0.240 \\
\hline Acid value & N.S & 0.440 & 0.430 & N.S & 0.410 & 0.443 & 0.460 \\
\hline Crude protein $(\%)$ & 0.177 & 21.59 & 23.25 & 0.217 & 22.30 & 23.95 & 21.01 \\
\hline Moisture (\%) & 0.232 & 13.20 & 12.60 & 0.565 & 12.60 & 11.90 & 12.01 \\
\hline Seed volume (mm3) & 0.654 & 13.50 & 12.54 & 0.762 & 12.00 & 13.96 & 12.98 \\
\hline Relative density & 0.004 & 0.768 & 0.771 & 0.003 & 0.774 & 0.765 & 0.769 \\
\hline Seed coat $(\%)$ & N.S & 37.72 & 38.97 & 1.650 & 36.98 & 38.81 & 37.90 \\
\hline Germination $(\%)$ & 0.288 & 81.024 & 87.325 & 0.353 & 78.21 & 86.26 & 88.08 \\
\hline \multicolumn{8}{|l|}{ Seedling vigor } \\
\hline (Radical length (cm) & 0.411 & 15.51 & 16.73 & 0.503 & 15.77 & 17.00 & 15.59 \\
\hline (Shoot length $(\mathrm{cm})$ & 0.295 & 14.09 & 15.22 & 0.361 & 14.17 & 15.24 & 14.48 \\
\hline Seedling dry weight (mg) & 0.622 & 55.36 & 54.06 & 0.982 & 52.90 & 55.30 & 53.06 \\
\hline
\end{tabular}

\section{3- Effect of different growing locations:}

Table 2 shows the average values of studied characters as affected by different growing location. The combined analysis showed highly significant differences in all studied characters due to location except free fatty acid $\%$ and acid value. The cotton grown at Gharbia and Dakahlia recorded the highest yield, boll weight (g) and seed index (g). While, Beheira location recorded the highest lint percentage. These results are in agreement with those obtained by Badr and Soad (2004b), Hassan et al. (2013), Abd El-Salam et al. (2014) and Shaker (2014). They reported that the effect of growing locations was significant in cotton and some yield components. Seed oil $\%$, protein $\%$, seed volume (mm3), seed coat \% and seed vigor for the cotton genotypes grown at Gharbia were higher than the other two locations. While, the less protein \% was for cotton grown at Dakahlia. Also, the lowest seed coat $\%$ was for cotton grown at Beheira. The highest seed volume was for cotton grown at Gharbia, while at Beheira was the lowest for these two characters. The highest germination $\%$ was for cotton grown at 
Dakahlia, while at Beheira was the less. The highest radical length, shoot length and seedling dry weight were for cotton grown at Gharbia than the other two locations. Theses results are in harmony with those obtained by Atteia (2001), El-Desuky (2002), Badr and Soad (2004 a), Badr and Soad (2004b), Amal et al. 2010 and Hassan et al. (2013). They reported that the effect of location was significant in most seed characters. This may belong to different environments in location to another.

4- Effect of interaction between cultivars and location:

Data in Table 3 show that the cultivars $\mathrm{x}$ location interaction were significant for all studied characters, except seed cotton yield and lint \%. Data indicate that cultivars differently at different locations. Gharbia location recorded the highest boll weight for Giza 86, Giza 94, Giza 92 and Giza 96. Giza 94 at Gharbia and Dakahlia recorded the highest seed index compared with Giza 86; also Giza 88, Giza 92 and Giza 96 surpassed on Giza 87 and Giza 93. Also, Giza 88 and Giza 93 at Dakahlia and Gharbia recorded the highest seed index. Beheira location gave the lowest values for boll weight and seed index for most cultivars.

Table 3. Effect of cultivars $x$ growing location interaction on seed cotton yield, viability and seed quality characters.

\begin{tabular}{|c|c|c|c|c|c|c|c|c|c|c|c|c|c|}
\hline \multirow[b]{2}{*}{ Characters } & \multirow{2}{*}{ L.S.D $D_{0.01}$} & \multicolumn{3}{|c|}{ Giza 86} & \multicolumn{3}{|c|}{ Giza 94} & \multicolumn{3}{|c|}{ Giza 87} & \multicolumn{3}{|c|}{ Giza 88} \\
\hline & & L1 & L2 & L3 & $\mathbf{L} \mathbf{1}$ & $\mathbf{L 2}$ & L3 & L1 & L2 & $\mathbf{L 3}$ & $\mathbf{L 1}$ & $\mathbf{L} 2$ & L3 \\
\hline Seed cotton yield $\mathrm{k} / \mathrm{f}$ & NS & 8.88 & 9.60 & 9.98 & 10.55 & 12.32 & 11.96 & 6.75 & 8.57 & 7.54 & 7.77 & 10.10 & 8.38 \\
\hline Boll weight (g) & 0.33 & 2.76 & 3.27 & 3.27 & 2.75 & 3.41 & 3.06 & 2.19 & 2.65 & 2.79 & 2.38 & 2.86 & 2.95 \\
\hline Lint $\%$ & NS & 39.23 & 38.53 & 38.58 & 42.29 & 40.61 & 40.49 & 34.80 & 32.78 & 32.90 & 37.89 & 36.85 & 36.73 \\
\hline Seed index $(g)$ & 0.82 & 9.64 & 11.64 & 11.20 & 10.49 & 13.12 & 12.66 & 8.70 & 10.64 & 10.68 & 8.65 & 11.13 & 11.63 \\
\hline Oil \% & 1.131 & 26.61 & 28.67 & 27.45 & 29.19 & 26.57 & 26.28 & 28.98 & 29.98 & 27.00 & 29.45 & 23.25 & 23.67 \\
\hline Free fatty acid $(\%)$ & 0.069 & 0.210 & 0.230 & 0.210 & 0.207 & 0.240 & 0.220 & 0.201 & 0.214 & 0.206 & 0.210 & 0.238 & 0.225 \\
\hline Acid value & 0.065 & 0.390 & 0.410 & 0.405 & 0.419 & 0.430 & 0.420 & 0.401 & 0.419 & 0.410 & 0.400 & 0.453 & 0.440 \\
\hline Crude protein $(\%)$ & 0.529 & 22.72 & 27.71 & 22.39 & 21.87 & 25.96 & 20.29 & 27.59 & 29.01 & 21.57 & 20.08 & 20.08 & 27.55 \\
\hline Moisture (\%) & 0.650 & 10.20 & 10.20 & 10.50 & 12.50 & 11.98 & 12.10 & 11.26 & 10.99 & 11.49 & 10.80 & 11.94 & 10.98 \\
\hline Seed volume (mm3) & 0.780 & 11.09 & 11.98 & 12.00 & 12.60 & 13.90 & 12.89 & 10.90 & 11.98 & 11.95 & $12 / 69$ & 13.60 & 12.90 \\
\hline Relative density & 0.007 & 0.762 & 0.743 & 0.767 & 0.783 & 0.766 & 0.786 & 0.769 & 0.768 & 0.766 & 0.771 & 0.772 & 0.775 \\
\hline Seed & 1.215 & 32.30 & 31.70 & 32.00 & 37.00 & 38.35 & 37.50 & 35.63 & 36.20 & 36.00 & 35.95 & 37.50 & 36.25 \\
\hline Germination $(\%)$ & 2.150 & 77.66 & 98.33 & 86.83 & 71.00 & 76.33 & 73.50 & 95.66 & 68.50 & 96.50 & 76.00 & 86.83 & 96.50 \\
\hline & & & & & & & & & & & & & \\
\hline Radical length $(\mathrm{cm})$ & & & & 14.80 & 13.07 & & 18.07 & 18.57 & 16.84 & 12.37 & 15.24 & & 14.37 \\
\hline Shoot length $(\mathrm{cm})$ & 0.701 & 12.15 & 18.61 & 11.91 & 13.55 & 13.68 & 18.28 & 18.55 & 11.71 & 11.58 & 13.78 & 14.71 & 11.71 \\
\hline $\begin{array}{l}\text { Seedling dry weight } \\
(\mathrm{mg})\end{array}$ & 0.923 & 51.00 & 53.28 & 52.90 & 49.00 & 52.62 & 50.61 & 47.90 & 48.90 & 48.00 & 52.60 & 57.89 & 55.96 \\
\hline
\end{tabular}

Continue table 3.

\begin{tabular}{lcccccccccc}
\hline \multicolumn{1}{c}{ Treatments } & \multicolumn{1}{c}{ L.S.D } & \multicolumn{3}{c}{ Giza 92 } & \multicolumn{4}{c}{ Giza 93 } & \multicolumn{3}{c}{ Giza 96 } \\
Characters & & L1 & L2 & L3 & L1 & L2 & L3 & L1 & L2 & L3 \\
\hline Seed cotton yield k/f & NS & 8.89 & 10.31 & 9.29 & 8.23 & 9.91 & 8.61 & 9.54 & 10.13 & 8.87 \\
Boll weight (g) & 0.33 & 2.78 & 3.08 & 2.96 & 2.50 & 2.57 & 2.90 & 2.79 & 3.11 & 2.96 \\
Lint \% & NS & 36.37 & 36.12 & 35.70 & 34.49 & 34.25 & 33.55 & 39.58 & 38.45 & 38.68 \\
Seed index (g) & 0.82 & 9.45 & 11.25 & 10.60 & 9.25 & 10.80 & 11.07 & 9.12 & 11.54 & 10.33 \\
Oil \% & 1.131 & 27.03 & 29.97 & 29.43 & 28.99 & 28.76 & 27.12 & 29.76 & 29.65 & 29.21 \\
Free fatty acid (\%) & 0.069 & 0.219 & 0.225 & 0.215 & 0.230 & 0.225 & 0.215 & 0.230 & 0.240 & 0.230 \\
Acid value & 0.065 & 0.407 & 0.420 & 0.409 & 0.400 & 0.410 & 0.405 & 0.395 & 0.430 & 0.410 \\
Crude protein (\%) & 0.529 & 20.66 & 20.55 & 20.40 & 21.54 & 21.45 & 20.57 & 28.56 & 29.22 & 25.33 \\
Moisture (\%) & 0.650 & 11.96 & 11.59 & 10.90 & 11.89 & 12.00 & 11.60 & 11.30 & 12.00 & 11.50 \\
Seed volume (mm3) & 0.780 & 11.50 & 12.90 & 11.89 & 11.80 & 11.98 & 11.50 & 12.00 & 12.90 & 11.87 \\
Relative density & 0.007 & 0.791 & 0.765 & 0.766 & 0.774 & 0.770 & 0.767 & 0.770 & 0.773 & 0.771 \\
Seed coat (\%) & 1.215 & 34.78 & 36.66 & 36.00 & 34.00 & 36.36 & 35.78 & 38.28 & 39.20 & 36.10 \\
Germination (\%) & 2.150 & 81.00 & 99.17 & 92.67 & 72.67 & 96.50 & 94.33 & 73.50 & 75.17 & 74.17 \\
Seedling vigor & & & & & & & & & & \\
Radical length (cm) & 1.091 & 15.81 & 13.34 & 15.38 & 16.08 & 14.51 & 18.34 & 16.81 & 20.06 & 15.78 \\
Shoot length (cm) & 0.701 & 14.55 & 15.98 & 13.02 & 12.62 & 14.82 & 20.42 & 14.02 & 17.15 & 14.45 \\
Seedling dry weight (mg) & 0.923 & 52.00 & 54.60 & 53.70 & 52.00 & 53.69 & 52.90 & 55.28 & 58.80 & 54.90 \\
\hline
\end{tabular}

*, ** and NS indicated $\mathbf{P}<\mathbf{0 . 0 5 \%}, \mathbf{P}<\mathbf{0 . 0 1 \%}$ and not significant, respectively. $\quad$ L1= El-Beheira $\quad$ L2= El-Gharbia $\quad$ L3= El-Dakahlia

As for Giza 92 at Gharbia region gave higher oil $\%$ and germination percentage, while Giza 92 at Dakahlia produced the highest relative density. Giza 96 cultivar recorded the highest values for seed coat (39.20), radical length and seedling dry weight for the cotton grown at Gharbia, while, Giza 96 at Dakahlia 
gave the lowest acid value. Giza 87 cultivar at Dakahlia gave the lowest free fatty acid. Giza 86 gave the lowest value of moisture \% at both Dakahlia and Ghrbia. Giza93 at Behira produced the highest shoot length. Giza 87 cultivars gave the lowest values for boll weight $(\mathrm{g})$, seed index $(\mathrm{g})$, oil \%, free fatty acid, acid value and seed volume were at Dakahlia. While, Giza 87 at Gharbia gave the lowest germination \% and shoot length. Theses results are in harmony with theses obtained by Badr and Soad (2004 a), Badr and Soad (2004b), Amal et al. 2009, Amal et al. 2010 and Hassan et al. (2013). They reported that the effect of location was significant in most seed characters.

5-Effect of the interaction between cultivars and growing seasons:

Table 4 show the average values of the studied cotton characters for the seven Egyptian cotton cultivars growing during the two successive seasons (2015 and 2016), all studied characters, except for lint \%, free fatty acid, acid value and shoot length were not significant effect. The cultivars Giza86, Giza 94 and Giza 96 during two seasons produced the highest boll weight; also Giza 94 during the $1^{\text {st }}$ season.

Table 4. Effect of cultivars $x$ growing season interaction on seed cotton yield, viability and seed quality characteristics.

\begin{tabular}{lccccccccc}
\hline \multicolumn{1}{c}{ Treatments } & \multirow{2}{*}{ L.S.D } & \multicolumn{2}{c}{ G86 } & \multicolumn{2}{c}{ G94 } & \multicolumn{2}{c}{ G87 } & \multicolumn{2}{c}{ G88 } \\
Characters & $\mathbf{2 0 1 5}$ & $\mathbf{2 0 1 6}$ & $\mathbf{2 0 1 5}$ & $\mathbf{2 0 1 6}$ & $\mathbf{2 0 1 5}$ & $\mathbf{2 0 1 6}$ & $\mathbf{2 0 1 5}$ & $\mathbf{2 0 1 6}$ \\
\hline Seed cotton yield k/f & NS & 10.46 & 8.51 & 13.15 & 10.07 & 8.12 & 7.12 & 9.61 & 7.89 \\
Boll weight (g) & 0.27 & 3.11 & 3.09 & 3.21 & 2.94 & 2.66 & 2.42 & 2.84 & 2.62 \\
Lint (\%) & NS & 38.91 & 38.65 & 41.03 & 41.23 & 33.19 & 33.79 & 37.20 & 37.12 \\
Seed index (g) & 0.67 & 11.51 & 10.14 & 13.17 & 11.02 & 10.79 & 9.22 & 11.44 & 9.50 \\
Oil (\%) & 2.556 & 27.63 & 29.52 & 26.35 & 27.35 & 27.51 & 29.51 & 25.19 & 27.19 \\
Free fatty acid (\%) & N.S & 0.200 & 0.210 & 0.200 & 0.220 & 0.209 & 0.218 & 0.210 & 0.229 \\
Acid value & N.S & 0.440 & 0.416 & 0.406 & 0.425 & 0.408 & 0.410 & 0.421 & 0.459 \\
Crude protein (\%) & 0.432 & 24.44 & 26.11 & 21.54 & 23.21 & 26.55 & 28.22 & 22.97 & 22.64 \\
Moisture (\%) & 0.36 & 13.00 & 12.76 & 12.00 & 11.00 & 11.65 & 12.00 & 11.95 & 12.80 \\
Seed volume (mm3) & 1.260 & 11.97 & 10.99 & 12.00 & 12.90 & 11.40 & 10.96 & 12.10 & 12.45 \\
Relative density & 0.005 & 0.762 & 0.764 & 0.777 & 0.779 & 0.766 & 0.769 & 0.762 & 0.769 \\
Seed coat (\%) & 1.240 & 35.36 & 35.00 & 36.90 & 37.97 & 36.09 & 36.76 & 36.00 & 37.41 \\
Germination (\%) & 1.219 & 84.72 & 90.50 & 71.11 & 78.11 & 83.61 & 90.16 & 84.16 & 89.94 \\
Seedling vigor & & & & & & & & & \\
(Radical length (cm) & 0.891 & 16.07 & 17.28 & 15.82 & 17.03 & 15.32 & 16.53 & 14.52 & 15.73 \\
(Shoot length (cm) & N.S & 13.64 & 14.81 & 14.58 & 15.75 & 13.36 & 14.53 & 12.82 & 13.98 \\
Seedling dry weight (mg) & 1.265 & 51.72 & 50.70 & 45.23 & 57.80 & 53.90 & 51.29 & 55.90 & 56.20 \\
\hline *** and NS indicated P<0.05\%, P<0.01\% and not significant, respectively. & & & & &
\end{tabular}

Continue Table 4

\begin{tabular}{lccccccc}
\hline & Treatments & \multirow{2}{*}{ L.S.D } & \multicolumn{2}{c}{ G92 } & \multicolumn{2}{c}{ G93 } & \multicolumn{3}{c}{ G96 } \\
Character & NS & 10.17 & 8.82 & 10.23 & 7.60 & 9.90 & 9.13 \\
Seed cotton yield k/f & 0.27 & 3.01 & 2.87 & 2.78 & 2.54 & 2.96 & 2.95 \\
Boll weight (g) & NS & 35.83 & 36.29 & 33.89 & 34.31 & 38.73 & 39.08 \\
Lint (\%) & 0.67 & 10.97 & 9.89 & 10.80 & 9.95 & 10.80 & 9.86 \\
Seed index (g) & 2.556 & 27.95 & 29.95 & 25.27 & 27.27 & 26.30 & 27.30 \\
Oil (\%) & N.S & 0.240 & 0.220 & 0.230 & 0.210 & 0.210 & 0.200 \\
Free fatty acid (\%) & N.S & 0.414 & 0.434 & 0.410 & 0.425 & 0.424 & 0.443 \\
Acid value & 0.432 & 20.37 & 21.03 & 20.06 & 21.72 & 27.20 & 28.87 \\
Crude protein (\%) & 0.36 & 11.96 & 11.00 & 11.23 & 11.05 & 11.69 & 11.06 \\
Moisture (\%) & 1.260 & 13.00 & 13.30 & 12.90 & 13.00 & 12.32 & 12.50 \\
Seed volume (mm3) & 0.005 & 0.772 & 0.775 & 0.763 & 0.766 & 0.770 & 0.772 \\
Relative density & 1.240 & 39.16 & 37.98 & 38.19 & 37.90 & 36.98 & 36.36 \\
Seed coat (\%) & 1.219 & 88.33 & 93.55 & 84.44 & 91.22 & 70.77 & 77.77 \\
Germination (\%) & & & & & & & \\
Seedling vigor & 0.891 & 14.23 & 15.45 & 15.70 & 16.92 & 16.94 & 18.15 \\
(Radical length (cm) & N.S & 13.93 & 15.10 & 15.36 & 16.53 & 14.62 & 15.79 \\
(Shoot length (cm) & 1.265 & 56.30 & 57.50 & 56.70 & 57.98 & 54.60 & 55.70 \\
Seedling dry weight (mg) & & & & & & $\mathbf{2 0 1 5}$ \\
\hline
\end{tabular}

*, ** and NS indicated $\mathrm{P}<0.05 \%, \mathrm{P}<0.01 \%$ and not significant, respectively.

G 92 during two seasons gave the highest oil\%. G 96 during $2^{\text {nd }}$ season gave the highest protein $\%$ and radical length (cm). G 94, G 88, G 92, G 93 and G 96 during both seasons produced the highest seed volume. G 92 and G 94 during two seasons gave the highest relative density. G 92 during $1^{\text {st }}$ season produced the highest seed coat. Giza 92 during $2^{\text {nd }}$ season produced the highest germination percentage. G 92 and G 93 during both seasons and G 94 during $2^{\text {nd }}$ season gave the highest seedling dry weight. G 87 during $2^{\text {nd }}$ season gave the lowest boll weight (g) and seed index. G 86 and G 87 during two seasons gave the lowest seed 
volume. G 96 during $1^{\text {st }}$ season gave the lowest germination, G 88 during $1^{\text {st }}$ season produced the lowest oil and radical length. G 92 during $1^{\text {st }}$ season gave the lowest protein \%. Theses results are in harmony with those obtained by Badr and Soad (2004 a), Badr and Soad (2004b), Amal et al. 2009, Amal et al. 2010 and Hassan et al. (2013). They reported that the effect of location was significant in most seed characters.

6- Effect of the interaction between growing location and season:

Table 5 shows the average values of the studied cotton characters for the three locations during the two successive seasons (2015 and 2016) and indicated that the all studied characters were significantly, except for lint $\%$ and seed volume.

The highest values for seed cotton yield, free fatty acid and acid value at Beheira in the $1^{\text {st }}$ season.
The highest boll weight, seed coat and germination were at Dakahlia in the $2^{\text {nd }}$ season, also Gharbia location equal significantly Dakhlia for boll weight.

The highest oil $\%$, protein $\%$, moisture, radical length and shoot length at Gharbia in $2^{\text {nd }}$ season. The highest values of seed index and seedling dry weight at Gharbia in $1^{\text {st }}$ season. The highest relative density at Beheira in $2^{\text {nd }}$ season. Therefore it could be concluded that the mean values of different traits varied from location to another according to the year of production. These results may belong to the each character needs suitable condition environment for the best quality. Theses results are in harmony with those obtained by Badr and Soad (2004 a), Badr and Soad (2004b), Amal et al. 2009, Amal et al. 2010 and Hassan et al. (2013). They reported that the effect of location was significant in most seed characters.

Table 5. Mean performance the effect of growing interaction and significantly the (C. X L. X Y.) interaction on seed cotton yield, viability and seed quality characteristics.

\begin{tabular}{|c|c|c|c|c|c|c|c|c|}
\hline \multirow[b]{2}{*}{ Characters } & \multirow{2}{*}{ L.S.D ${ }_{0.01}$} & \multicolumn{2}{|c|}{ El-Beheira } & \multicolumn{2}{|c|}{ El-Gharbia } & \multicolumn{2}{|c|}{ El-Dakahlia } & \multirow{2}{*}{ CxLxY } \\
\hline & & Y1 & Y2 & Y1 & Y2 & Y1 & Y2 & \\
\hline Seed cotton yield k/f & 2.09 & 11.32 & 5.99 & 10.06 & 10.20 & 9.31 & 9.15 & N.S \\
\hline Boll weight (g) & 0.30 & 2.94 & 2.25 & 2.99 & 2.99 & 2.88 & 3.09 & $* *$ \\
\hline Lint $(\%)$ & N.S & 37.40 & 38.22 & 36.91 & 36.69 & 36.60 & 36.72 & N.S \\
\hline Seed index $(\mathrm{g})$ & 0.93 & 11.24 & 7.41 & 11.68 & 11.22 & 11.14 & 11.19 & N.S \\
\hline Oil (\%) & 2.286 & 27.33 & 28.33 & 26.87 & 29.81 & 25.32 & 26.32 & N.S \\
\hline Free fatty acid (\%) & 0.035 & 0.236 & 0.203 & 0.203 & 0.199 & 0.220 & 0.230 & $* *$ \\
\hline Acid value & 0.025 & 0.490 & 0.410 & 0.443 & 0.470 & 0.414 & 0.468 & $* *$ \\
\hline Crude protein $(\%)$ & 0.307 & 22.31 & 24.31 & 24.45 & 25.46 & 21.01 & 23.01 & $* *$ \\
\hline Moisture (\%) & 0.965 & 11.50 & 10.98 & 12.59 & 12.30 & 11.99 & 11.59 & $* *$ \\
\hline Seed volume (mm3) & N.S & 11.70 & 11.95 & 13.09 & 13.29 & 12.50 & 12.97 & $* *$ \\
\hline Relative density & 0.006 & 0.773 & 0.775 & 0.764 & 0.767 & 0.768 & 0.771 & $* *$ \\
\hline Seed coat $(\%)$ & 1.250 & 37.50 & 35.98 & 37.36 & 36.43 & 38.20 & 38.98 & $* *$ \\
\hline Germination (\%) & 0.499 & 74.76 & 81.67 & 83.45 & 89.08 & 84.86 & 91.24 & $* *$ \\
\hline Seedling vigor & & & & & & & & \\
\hline (Radical length (cm) & 0.712 & 15.00 & 16.55 & 16.73 & 17.28 & 14.81 & 16.36 & $* *$ \\
\hline (Shoot length $(\mathrm{cm})$ & 0.364 & 13.42 & 14.92 & 14.99 & 15.49 & 13.73 & 15.23 & N.S \\
\hline Seedling dry weight $(\mathrm{mg})$ & 0.456 & 52.00 & 53.01 & 57.50 & 56.36 & 55.56 & 55.00 & N.S \\
\hline
\end{tabular}

*, ** and NS indicated $\mathrm{P}<0.05 \%, \mathrm{P}<0.01 \%$ and not significant, respectively.

\section{7- Effect of second order interaction:}

Table 5 shows that the ( $\mathrm{C} \times \mathrm{Y} \times \mathrm{L}$ ) was significant on studied characters, except for seed cotton yield, lint $\%$, seed index (g), oil \%, shoot length and seedling dry weight. These results were in accordance with those obtained by Badr (2003), Badr and Soad (2004 a), Badr and Soad (2004b), Hassan et al (2013), Abd El-Salam et al. (2014) and Shaker (2014). They reported that the effect of cultivars $(\mathrm{C})$, location $(\mathrm{L})$, year $(\mathrm{Y})$ and the interaction between them were significant on yield and yield components characters. Also Atteia (2001), El-Desuky (2002), Badr and Soad (2004 a), Badr and Soad (2004b), Hassan et al (2013) and Abd El-Aty et al. (2015), they reported that effects were significantly on some cotton seed quality characters. However, Gipson and Joham (1969), Quisenberry and Gipson (1974) and Thomson (1979), they reported that effect of environmental conditions was significant on some seed quality and seed viability characters.

\section{8- Correlations between studied characters:}

Results in Table 6 indicated significant Positive significant correlations were found between seed cotton yield and both (boll weight and seed index), lint percentage and each (boll weight, seed volume and seed coat), boll weight and seed coat $\%$, seed index and both (seed volume and seedling dry weight), free fatty acid and acid value, protein $\%$ and seed coat $\%$, seed volume and seedling dry weight, germination $\%$ and both (shoot length and seedling dry weight), shoot length and seedling dry weight.

The cultivar Giza 94 gave higher seed index than both Giza 92 and G 96 and it gave higher seed volume than each of Giza 92, Giza 93, Giza 96 and Giza 88. Giza 92 it gave higher germination \%, Giza 96 gave higher radical length and seedling dry weight, this cultivar (G 88) gave the less than other genotypes for seed cotton yield, germination $\%$ and seedling dry weight. Its recommended by this correlations in the breeding program to improve seed cotton yield and seed characters. Some our results were in accordance with those obtained by Badr (2003), Badr and Soad (2004 a) and Badr and Soad (2004b), they reported that the relationship between seed cotton yield, boll weight and lint percentage was positive and significant. Atteia (2001), El-Desuky (2002), Badr and Soad (2004 a) and Badr and 
Soad (2004b) reported that the correlation between (seed index and seed volume) was positive and significant while the correlation between (seed relative density and seed volume) was negative and significant. Hopper and MoDaniel (1999) who reported that improved seed vigor through genetic improvement programs. This correlation in the breeding program to improve seed cotton yield and cotton seed characters. Also, Leffler and Williams (1983) and Finch (1995), they reported that both seed size and density are correlated with planting seed quality. El-Desuky (2002) reported that the correlation among (seed oil \% and protein \%) was negative and significant.

Table 6. Correlation coefficient between studied characters of seven Egyptian cotton cultivars combined over two years on three location.

\begin{tabular}{|c|c|c|c|c|c|c|c|c|c|c|c|c|c|c|c|c|}
\hline X16 & X15 & X14 & X13 & $\mathrm{X} 12$ & X11 & $\mathbf{X 1 0}$ & X9 & X8 & $\mathbf{X} 7$ & X6 & X5 & X4 & $\mathbf{X 3}$ & $\mathbf{X} 2$ & Characters & \\
\hline-0.1639 & $-0.4128^{* *}$ & -0.0580 & -0.3468 & 0.2764 & 0.1629 & -0.3650 & $-0.1450-$ & -0.0183 & 0.2138 & 0.2185 & -0.002 & $0.3065^{*}$ & $0.6056^{* *}$ & 0.0639 & $\begin{array}{l}\text { Seed cotton } \\
\text { yield } \mathrm{k} / \mathrm{f}\end{array}$ & $\mathrm{X} 1$ \\
\hline-0.0475 & $-0.517 * *$ & -0.2027 & -0.1299 & $0.3264 *$ & $-0.4118^{* *}$ & $0.3115^{*}$ & -0.0474 & 0.1806 & 0.1284 & 0.1231 & -0.2626 & 0.0827 & $0.2965^{*}$ & & Lint $(\%)$ & $\mathrm{X} 2$ \\
\hline-0.0472 & $-0.4278 * *$ & -0.2027 & $-0.3335^{*}$ & $0.3837 * *$ & -0.0472 & 0.1349 & $0.1355-$ & $-0.1689-$ & -0.0846 & -0.0866 & -0.2717 & 0.0828 & & & Boll weight (g) & $\mathrm{X} 3$ \\
\hline $0.5202 * *$ & 0.0897 & 0.0547 & 0.2096 & $-0.3313^{*}$ & 0.1248 & $0.7147^{* *}$ & $0.2555-$ & $-0.3064 *$ & -0.1843 & -0.2031 & 0.0935 & & & & Seed index (g) & $\mathrm{X} 4$ \\
\hline 0.2118 & 0.3163 & 0.2175 & 0.2022 & $-0.5523^{* *}$ & 0.0702 & -0.1264 & $-0.3161 *_{-}$ & $-0.3075^{*}$ & -0.1203 & -0.0966 & & & & & Oil (\%) & $\mathrm{X} 5$ \\
\hline-0.1591 & 0.0357 & 0.0229 & -0.0451 & 0.1025 & -0.1617 & -0.0735 & $0.3023 *$ & 0.1754 & $0.9761^{* *}$ & & & & & & $\begin{array}{l}\text { Free fatty acid } \\
(\%)\end{array}$ & X6 \\
\hline-0.1393 & 0.0352 & 0.0128 & -0.0447 & 0.1148 & -0.1712 & -0.0490 & -0.2884 & 0.1967 & & & & & & & Acid value & $\mathrm{X} 7$ \\
\hline-0.1558 & 0.0845 & -0.1957 & 0.0607 & $0.3267^{*}$ & -0.2297 & -0.1193 & 0.1192 & & & & & & & & $\begin{array}{l}\text { Crude protein } \\
(\%)\end{array}$ & $\mathrm{X} 8$ \\
\hline 0.1498 & -0.1216 & -0.1752 & -0.0243 & 0.2070 & -0.0786 & 0.2645 & & & & & & & & & Moisture (\%) & X9 \\
\hline $0.5005 * *$ & 0.2603 & 0.0336 & 0.2614 & -0.1885 & $-0.5707 * *$ & & & & & & & & & & $\begin{array}{l}\text { Seed volume } \\
(\mathrm{mm} 3)\end{array}$ & $\mathrm{X} 10$ \\
\hline 0.1484 & -0.2426 & 0.0521 & -0.1026 & 0.1384 & & & & & & & & & & & $\begin{array}{l}\text { Relative } \\
\text { density }\end{array}$ & $\mathrm{X} 11$ \\
\hline$-0.4027 * *$ & $-0.4963 * *$ & 0.1874 & $-0.4547 * *$ & & & & & & & & & & & & Seed coat $(\%)$ & $\mathrm{X} 12$ \\
\hline $0.3995 * *$ & $0.4312 * *$ & 0.1587 & & & & & & & & & & & & & $\begin{array}{l}\text { Germination } \\
(\%)\end{array}$ & $\mathrm{X} 13$ \\
\hline \multicolumn{17}{|c|}{ Seedling vigor } \\
\hline-0.1761 & 0.1537 & & & & & & & & & & & & & & $\begin{array}{l}\text { (Radical length } \\
(\mathrm{cm})\end{array}$ & X14 \\
\hline $0.3912 * *$ & & & & & & & & & & & & & & & $\begin{array}{l}\text { (Shoot length } \\
\text { (cm) }\end{array}$ & $\mathrm{X} 15$ \\
\hline 1.00 & & & & & & & & & & & & & & & $\begin{array}{l}\text { Seedling dry } \\
\text { weight }(\mathrm{mg})\end{array}$ & $\mathrm{X} 16$ \\
\hline
\end{tabular}

\section{REFERENCES}

A.O.A.C. (1990). Official Method of Analysis of the Association of Official Analytical Chemists 15th (Edition, published by Association of Official Analytical Chemists Arlington, Virginia USA.).

Abd El- Salam, M. E., S. A. Shaker, A. E. I. Darwesh and S. S. M. Badr (2014). Evaluation of some cotton lines under different environmental conditions. J. Agric. Res. Kafr El- Sheikh Univ., 40(4):804-818.

Abd El-Aty, M. S., A. M. Omar, M. M. El-Lawendy and I. A. El-badaly (2015). Genetic studies seed quality in sorie Egyptian cotton (G. Barbadense L.). J. Agric. Res. Kafr El-Sheikh Univ., 41(1):91-117.

Amal, S. Mohamed, Azza, A. Mahmoud and S. S. M. Badr. (2010). Evaluation of some Egyptian cotton varieties for some seed chemical quality characters. J. Agric. Res. KafEl-Sheikh Univ. 36(1):33-38.

Amal, S. Mohamed; S. M. Saleh and Azza; A. Mahmoud (2009). Varietal and seasonal variations in chemical components of cotton seed and fiber of Egyptian cotton over six successive years. J. Biol. Chem. Environ. Sci., Vol. 4(4): 83-96.

Attiea, R. E. (2001). Variability in cotton seed quality: Its Measurement and Use. M. Sc. Thesis, Fac. Agric. Cairo Univ.
Badr, S. S. M (2003). Comparative evaluation of promising hybrid Giza84x (Giza 74x Giza 68) and extra-long staple cotton varieties grown in North Delta. Egypt. J. Agric. Res., 81 (3):1149-1169

Badr, S.S.M and Soad, A. El-Sayed (2004a). Evaluation of some extra long staple Egyptian cotton genotypes for yield, seed quality and viability characters. J. Agric. Res. Tanta Univ., 30 (2): 281-303.

Badr, S.S.M and Soad, A. El-Sayed (2004b). Evaluation of some extra long staple Egyptian cotton genotypes for yield, seed quality and viability characters. J. Agric. Res. Tanta Univ., 30 (2): 304-326.

El-Desuky, S. I., (2002). Variability and covariability for seed quality in Egyptian cotton. M. Sc. Thesis, Fac. Agric. Cairo. Univ..

Finch-Savage, W. E. (1995). Influence of seed quality on crop establishment growth, and yield. In, Seed Quality, A. S. Basra; An impriut of Haworth Press, Inc. New York, London, Norwood (Australia) SB 118.25.S 44.

Gipson, J. R., and H. E. Joham (1969). Influence of night temperature on growth and development of cotton (Gossypium hirutum L.) IV. Seed quality. Agric. Jou. 61:365-367. 
Hassan, S. A. M.; O. D. M. Nour; S. M. Saleh and Rokaya, M. Hassan (2013). Evaluation of some Egyptian cotton extra long staple genotypes grown at different environments for yield components, fiber quality and chemical treatments. Egypt. J. of Appl. Sci. 28(1):14-28.

Hopper, N. W.; and R. G. McDaniel (1999). The cotton seed : Origin, History, Technology, and production, edited by Wayne C. Smith: ISBN., 1999 John Wiley \&Sons. Inc.

I.S.T.A. (1995). Handbook of vigour Test Methods 3rd Edition, 1995. Published by The International Seed Testing Association.

I.S.T.A. (1999). International rules for Seed Testing Association. Seed Sci. \& Technol, 27, 155-165.

Kramer, A. and B. A. Twigg, (1962). Fundamental of Quality Control for the Food Industry. AVI publishing Co. West port, CT, pp. 512.

Leffler, H. R. and R. D. Williams (1983). Seed density classification influences germination and seedling growth of cotton. Crop Sci. 23:161-165.

Mclntosh, M.S. (1983). Analysis of combined experiments. Agron. J., 75: 153 - 155.

Quisenberry, J. E. and J. R. Gipson (1974). Growth and productivity of cotton grown from seed produced under four night temperatures. Crop Sci. 14:300302 .
Senedcor, G. W. and W. G. Cochron (1982). Statistical methods, applied to experiments in agriculture and biology. Seventh Edition, the Iowa State Univ. Press, Ames, Iowa, USA.

Shaker S. A. (2014). Comparative evaluation of two Egyptian extra long staple promising liens with cultivated commercial cotton varieties grown at Delta. J. Agric. Kafr El-Sheikh Univ. 40(1):2743.

Shehata, A. M. E; El-Ruby, M. M. and Mesallam, S. A. (1985a). Relationship between properties of dry cooked faba beans (Vicia faba L.). J. Food Quality, 7:209-218.

Steel, R. G. M. and J.H. Torrie. 1980. Principles and procedures of statistics. Second Edit Mc Graw Hill Book Co. New York, U.S.A.

Thomson, J. R.(1979). An introduction to seed technology. Wiley, NY. Youssef, M. M. (1978). Study of factors affecting the cookability of faba beans (Vicia faba L.). Ph. D. Thesis, Faculty of Agric, Univ. of Alexandria, Egypt.

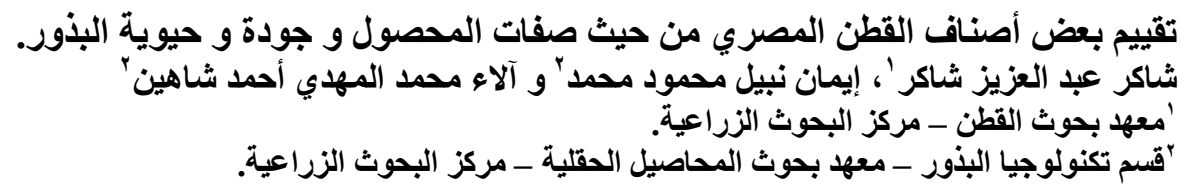

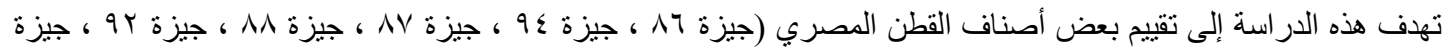

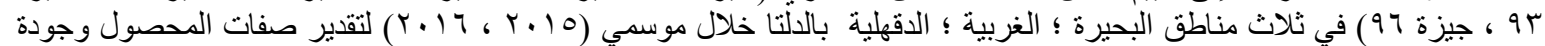

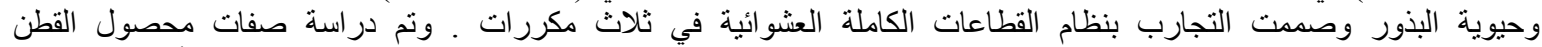

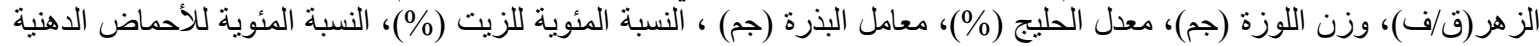

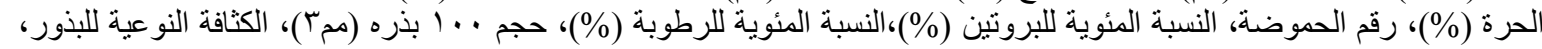

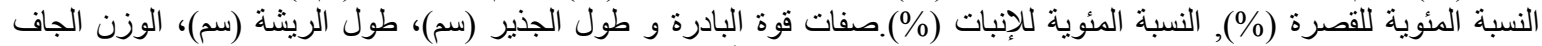

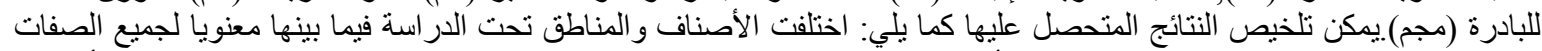

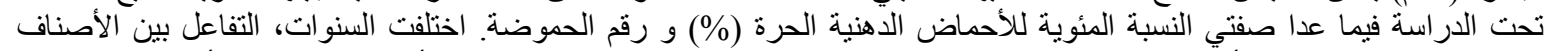

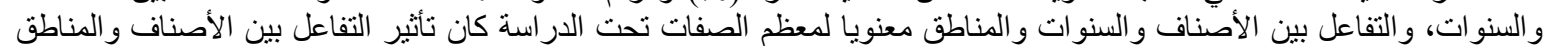

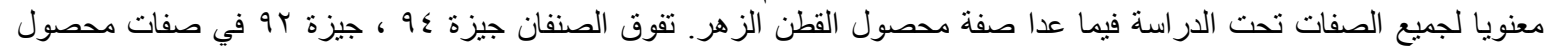

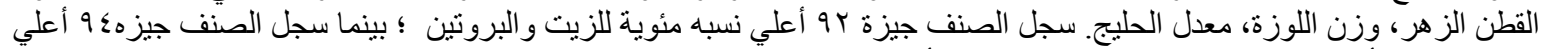

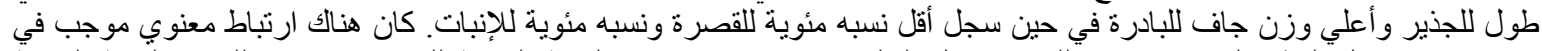

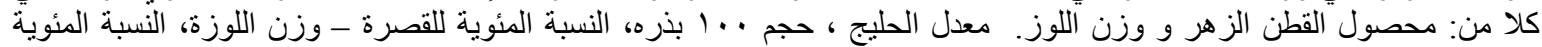

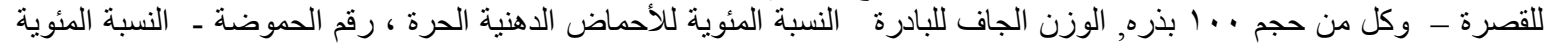

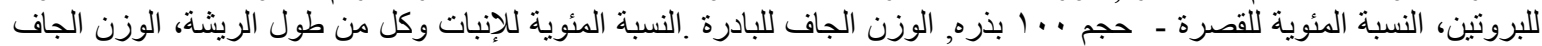

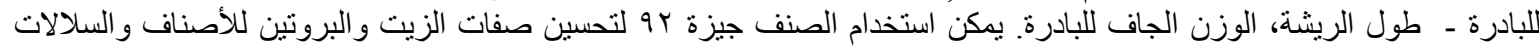
الجديدة. كما يمكن الاستفادة من نتائج الارتباط بين الصفات في بر امج التربية لتحسين المحصول التحن وصفات البذرة. 